WIDER Working Paper 2018/174

\title{
Inequality in China
}

Development, transition, and policy

Shi Li, ${ }^{1}$ Terry Sicular, ${ }^{2}$ and Finn Tarp ${ }^{3}$

December 2018 
Abstract: In this paper we describe the major trends in China's income inequality over the past 40 years and explain them as the outcome of four interleaved stories. The first story is a standard development story characterized by structural change, market development, labour absorption, and the Kuznets inverted-U path of inequality. The second is the economic transition story, in which changes in income distribution result from the shift from plan to market. Third is incomplete transition, with opportunities for rent-seeking, corruption, and hidden income. Fourth is the story of government efforts to moderate inequality through social and welfare policies.

Keywords: China, inequality, development, transition, welfare policy JEL classification: D31, O15, O53, P20

Acknowledgements: We acknowledge and thank UNU-WIDER for support of this research.

This study is a synthesis of the working papers produced under the Chinese component of the UNU-WIDER project 'Inequality in the giants'.

\footnotetext{
${ }^{1}$ Beijing Normal University, Beijing, China; ${ }^{2}$ University of Western Ontario, London, Canada, corresponding author, e-mail: sicular@uwo.ca; ${ }^{3}$ UNU-WIDER, Helsinki, Finland, and University of Copenhagen, Copenhagen, Denmark.

This study has been prepared within the UNU-WIDER project on 'Inequality in the Giants'.

Copyright (C) UNU-WIDER 2018

Information and requests: publications@wider.unu.edu

ISSN 1798-7237 ISBN 978-92-9256-616-6 https://doi.org/10.35188/UNU-WIDER/2018/616-6
}

Typescript prepared by Lesley Ellen.

The United Nations University World Institute for Development Economics Research provides economic analysis and policy advice with the aim of promoting sustainable and equitable development. The Institute began operations in 1985 in Helsinki, Finland, as the first research and training centre of the United Nations University. Today it is a unique blend of think tank, research institute, and UN agency — providing a range of services from policy advice to governments as well as freely available original research.

The Institute is funded through income from an endowment fund with additional contributions to its work programme from Finland, Sweden, and the United Kingdom as well as earmarked contributions for specific projects from a variety of donors.

Katajanokanlaituri 6 B, 00160 Helsinki, Finland

The views expressed in this paper are those of the author(s), and do not necessarily reflect the views of the Institute or the United Nations University, nor the programme/project donors. 
In the late 1970s, China embarked on a major programme of economic transition and reform. Since that time, China's economy has been transformed from a socialist planned economy to a predominately market economy characterized by a combination of state, private, and mixed ownership forms. This transformation has been accompanied by remarkable economic growth and structural change, with positive consequences for household incomes and standards of living. Over the past forty years household incomes have risen six-fold, poverty has declined dramatically, and in recent years a new class of ultra-rich has emerged.

These developments have naturally led to questions about trends in inequality in China, the topic of a growing literature that has employed a variety of empirical approaches and available data. Here we give a summary of the major trends in household income inequality in China, but our main aim is to go one step further and explain these trends in the context of China's broader economic development and transition.

In our view, the evolution of income inequality in China over the past 40 years is the net result of four interleaved stories. The first story is a standard development story characterized by structural change, growing market integration, and labour absorption, which together are associated with a Kuznets inverted-U path of inequality. The second is the economic transition story, in which the shift from a planned to a market economy generates increased differentiation of incomes. Third is the story of incomplete transition, which generates opportunities for rent-seeking, corruption, and hidden income, with obvious implications for inequality. Fourth is the story of government efforts to moderate inequality, which efforts have expanded over time and led to the establishment of a range of new social and welfare programmes.

Below, we discuss in turn each of these stories and their relationship to the evolution of China's income inequality. We begin with a review of major trends in income inequality in China since the late 1980s.

\section{Income inequality in China: major trends}

Although different studies provide somewhat different estimates of China's Gini coefficient and related variables, general agreement exists regarding the key trends. Here we highlight several of the main trends and report inequality estimates mainly from a recent set of studies based on the China Household Income Project (CHIP) surveys, specifically, Cai and Yue (2018), Gustafsson and Wan (2018), Li et al. (2018), and Luo et al. (2018), as well as chapters of Li et al. (forthcoming). The CHIP surveys are large, nationwide, repeated (1988, 1995, 2002, 2007, and most recently 2013), cross-section household sample surveys spanning all major regions of China. Using the CHIP data, researchers have traced a consistent, detailed picture of incomes and inequality in China from the late 1980s through 2013. The findings of the CHIP studies are generally consistent with those reported elsewhere.

What are the main findings of these studies? First and most importantly, from the late 1980s through 2007 China experienced a long-term increase in income inequality. As shown in Figure 1, which shows estimates based on the CHIP data as well as official estimates from the National Bureau of Statistics (NBS), during these two decades China's income Gini rose from 0.38 to 0.49, so that by 2007 inequality in China was at a level similar to that in Mexico and not much lower 
than in Brazil, countries with moderately high inequality by international standards. More recent estimates, however, reveal that thereafter inequality began to decline.

Figure 1: China's Gini coefficient

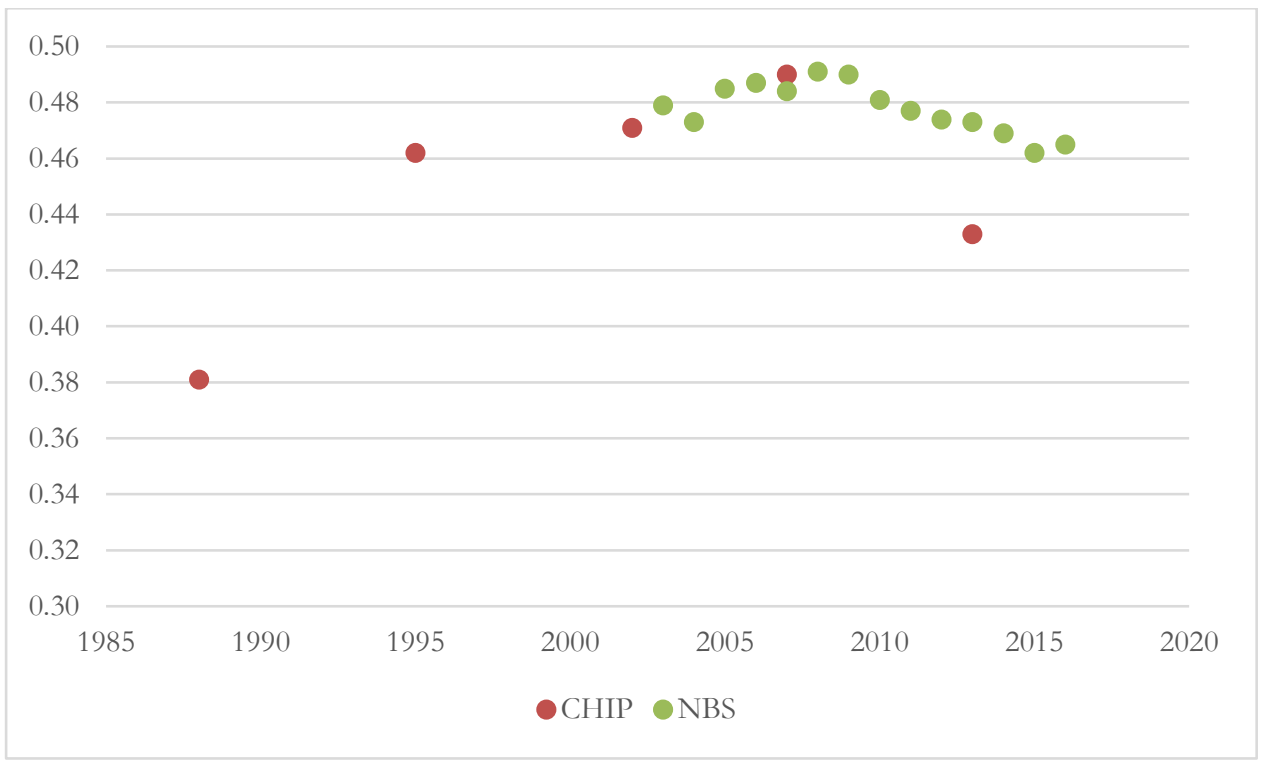

Notes: The NBS Gini coefficients are those published by the NBS using its estimates of household income per capita. The CHIP Gini coefficients are calculated using the CHIP survey data and an estimate of household income per capita that adjusts the NBS income variable in several ways, e.g. to include estimates of imputed rent on owner-occupied housing and of the implicit subsidies on subsidized rental housing.

Sources: Authors' illustration based on Luo et al. (2018), Department of Household Surveys (NBS 2016b: 407), and China Net (2017).

The recent decline in China's inequality is the subject of some discussion and debate. It is generally believed that household survey samples do not fully capture the ultra-rich population and that consequently income inequality estimates based on household survey data understate actual inequality. In China this problem has recently become a concern due to the expansion of private wealth and the emergence of a growing class of the super-rich.

Some recent studies attempt to address this problem. Li et al. (2018) use available information about the income and wealth of China's super-rich to construct a top-income dataset, which is then combined with the CHIP household survey data as the basis for revised estimates of inequality. The results are striking. China's 2013 Gini coefficient jumps to over 0.6, noticeably higher than the Gini calculated from the original CHIP survey data. Luo et al. (2018) carries out a similar exercise. It uses data from the Hurun and Forbes rich lists to construct the top tail of the income distribution. The resulting estimates of China's Gini coefficient are higher in both 2007 and 2013, but especially in 2013. This study's estimates imply that between 2007 and 2013 China's Gini coefficient increased by at least 10 per cent and perhaps by as much as 40 per cent. Such exercises necessarily rely on incomplete information, and so the resulting estimates are imprecise. Nevertheless, they raise questions about the apparent decline in China's inequality since 2007.

A second main finding is that China's twenty-year long rise in inequality was not due to declining incomes of poorer segments of the population. In fact, incomes rose substantially throughout the income distribution, including for the poor. The income increases, however, were more rapid for richer segments of the population. This pattern is apparent in the growth incidence curves of household income per capita between various rounds of the CHIP survey (Figure 2). 
Figure 2: Growth incidence curves for China

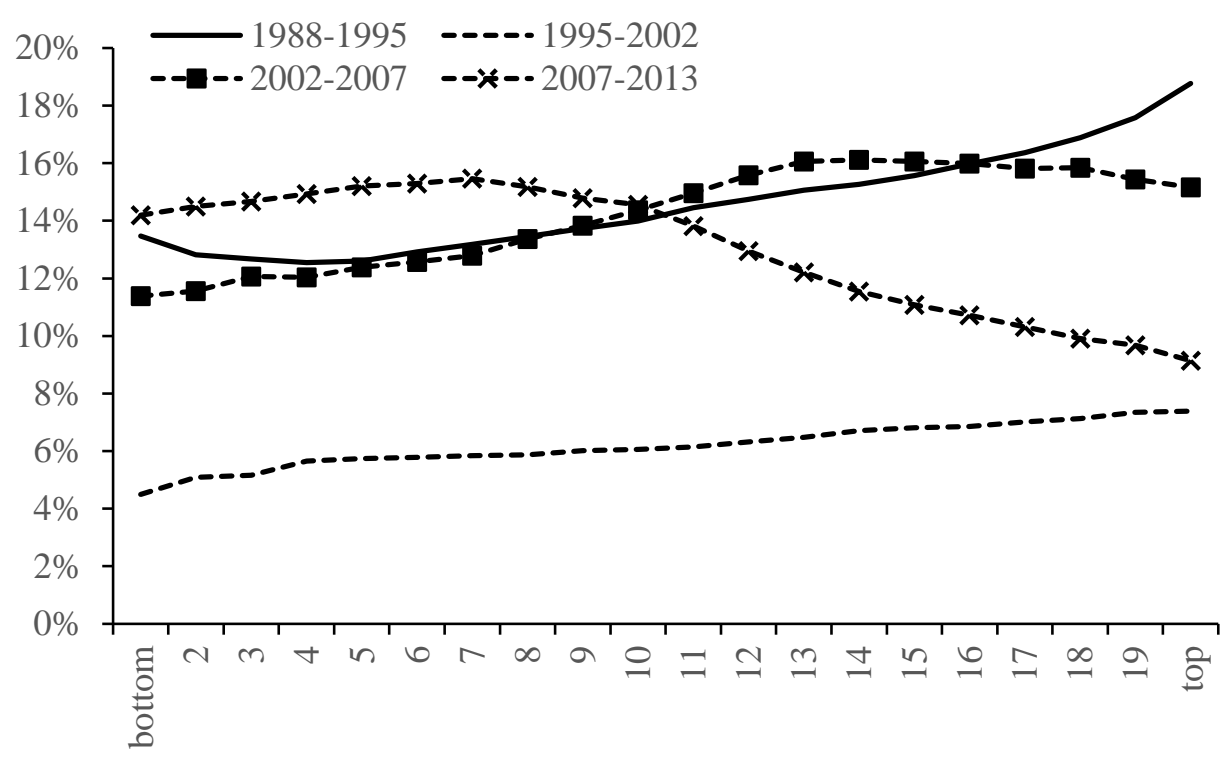

Note: Growth of household income per capita, constant prices, by ventile.

Source: Authors' calculations based on data from CHIP (China Institute for Income Distribution n.d.) and Luo et al. (2018).

Third, the trends in China's inequality both before and since 2007 are associated with changes in regional and sectoral income gaps, specifically the widening and then narrowing of income gaps between urban and rural areas and among regions. As shown in Table 1, the ratio of urban to rural incomes rose from 2.5 in 1988 to a high of 4.0 in 2007, after which it declined back to 2.6. The ratio between incomes in the relatively rich East and in the poorer Centre and West regions show a similar rise and fall.

Table 1: China's regional and urban/rural income gaps

\begin{tabular}{llllll}
\hline & 1988 & 1995 & 2002 & 2007 & 2013 \\
\hline Urban/Rural & 2.45 & 2.58 & 3.20 & 4.02 & 2.56 \\
East/Centre & 1.42 & 1.75 & 1.86 & 1.84 & 1.53 \\
East/West & 1.62 & 2.16 & 2.05 & 2.23 & 1.59 \\
\hline
\end{tabular}

Note: The income gaps reported in this table are equal to the ratios of average household income per capita in the different regions/sectors. Urban refers to urban residents with urban household registration and does not include rural-to-urban migrants.

Source: Authors' calculations based on data from CHIP (China Institute for Income Distribution n.d.) and Luo et al. (2018).

Fourth, trends in China's inequality have been associated with underlying changes in the sources of household income and their distribution. The rise in inequality from the 1980s through 2007 was associated with a declining share of income from more equally distributed sources, especially agriculture, and an increasing share of income from more unequally distributed sources of income such as assets (Figure 3). It also reflects changes in the distribution of some major sources of income. Notably, inequality in the distribution of wage earnings, which since the early 2000s has been the largest single source of household income, rose from 1988 through 2007, after which it declined. 
Figure 3: The composition of household income in China

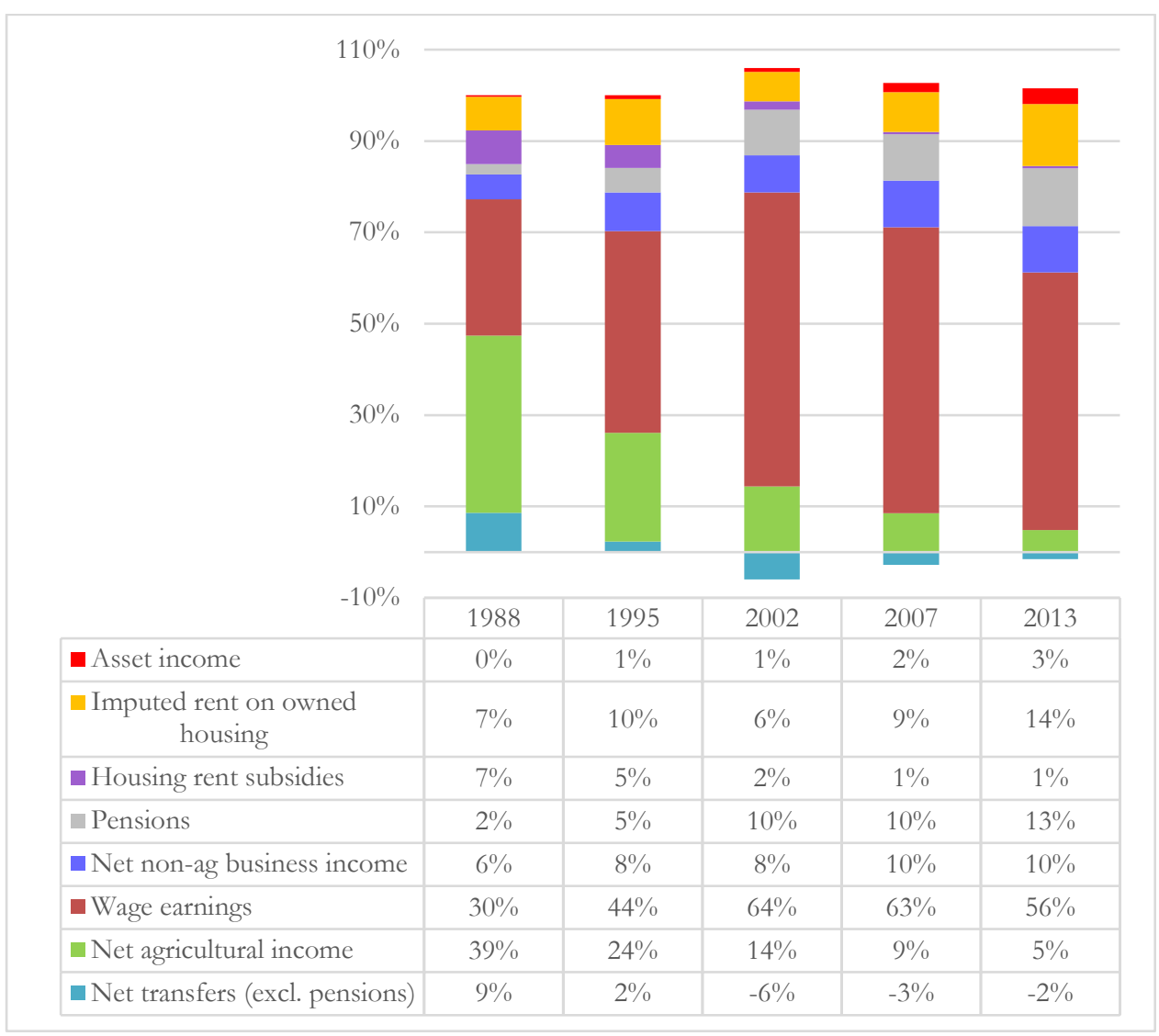

Source: Authors' calculations using data from CHIP (China Institute for Income Distribution n.d.) and adaptation from Luo et al. (2018).

Wages are the most important component of income but only part of the inequality story. In urban China the share of wage earners has in fact been declining and non-wage sources of income have played an increasingly important role in the distributional story. An important component of nonwage income in China is government transfers. A study by Cai and Yue (2018) finds that from 2002 to 2013 government social security transfers increased substantially and became more equalizing. Nevertheless, China's largest single transfer programme-pensions-are very unequally distributed. Pensions, which on average account for more than 10 per cent of household income in China, go overwhelmingly to a minority of the population-urban retirees. Without pensions, urban retirees would be poor, but the size of urban pensions is so large that their pension incomes make them relatively rich. Consequently, on the margin, government pensions are disequalizing.

\section{Economic development, structural change, and the Kuznets inverted U}

The Kuznets inverted-U hypothesis postulates that, with growth and development, inequality will initially increase but eventually, at higher levels of per capita income, level off and decline. Evidence on whether countries follow the Kuznets inverted $U$ is mixed; nevertheless, the hypothesis provides a useful framework for understanding key mechanisms that can drive inequality during development.

One mechanism underlying the inverted $\mathrm{U}$ is the spread of growth across the economy through linkages. Economic growth typically starts in a few sectors and regions. The benefits of initial growth go to a relatively small share of the population in those sectors and regions, thus creating 
inequality. Over time, if linkages exist to the rest of the economy and if growth continues, the benefits can spread more widely. For example, if factor markets are sufficiently developed to permit mobility, then labour and capital with low returns can move to opportunities that yield higher returns. Over time, such movement will equalize the returns to capital and incomes. The resulting regional catch-up, migration, and structural change help move the economy along to the downward section of the inverted $U$.

In countries with surplus labour the inverted $U$ is associated with a Lewis-type path of economic development. In such economies, during the initial stages of growth most of the population is in the traditional sector, which is characterized by low productivity, surplus labour, and underemployment or disguised unemployment. Surplus labour in the traditional sector supplies cheap labour to the modern sector and allows a 'grace period' during which the modern sector can expand rapidly with low wage costs. Growth during this phase benefits investors and entrepreneurs as well as relatively better paid workers in the modern sector, causing inequality to rise. With continued growth, however, the labour surplus is absorbed and eventually exhausted. In the later stages of development, labour scarcity leads to rising wages nationwide, thus moderating inequality. According to this scenario, the inverted $U$ is associated with structural change, labour mobility, and changes in the composition of income between incomes from capital versus labour.

Studies of income inequality in China show evidence of regional catch-up associated with structural change, migration, and changes in employment and income composition. As shown in Table 1 and consistent with the Kuznets hypothesis, inter-regional income gaps in China widened from 1988 through 2007, during which period income growth in relatively rich eastern China outpaced that in central and western regions. From 2007 to 2013, however, the between-region gaps shrank, reflecting regional catch-up. Of relevance to the Lewis model, the urban-rural income gap also widened and reached a maximum of 4.0 in 2007 , a very high level by international standards. After 2007, this trend reversed and the urban-rural income gap narrowed (Table 1).

China's experience of ongoing, large-scale migration and in recent years rising wages and shortages of unskilled labour are consistent with the Lewis story. At the start of the economic reform era, China was generally believed to have been a labour surplus economy characterized by a large labour force overwhelmingly employed in low-productivity agriculture. The shift from collective farming to household farming increased farm productivity and freed rural workers, who then began to transfer into higher productivity non-farm employment. The aggregate statistics in Figure 4 reveal the structural change in employment that has been ongoing since the 1980s, such that by the early 2000s fewer than half of employed workers in China were primarily employed in agriculture. 
Figure 4: Primary sector employment in China as a share of total employment (per cent) 1980-2015

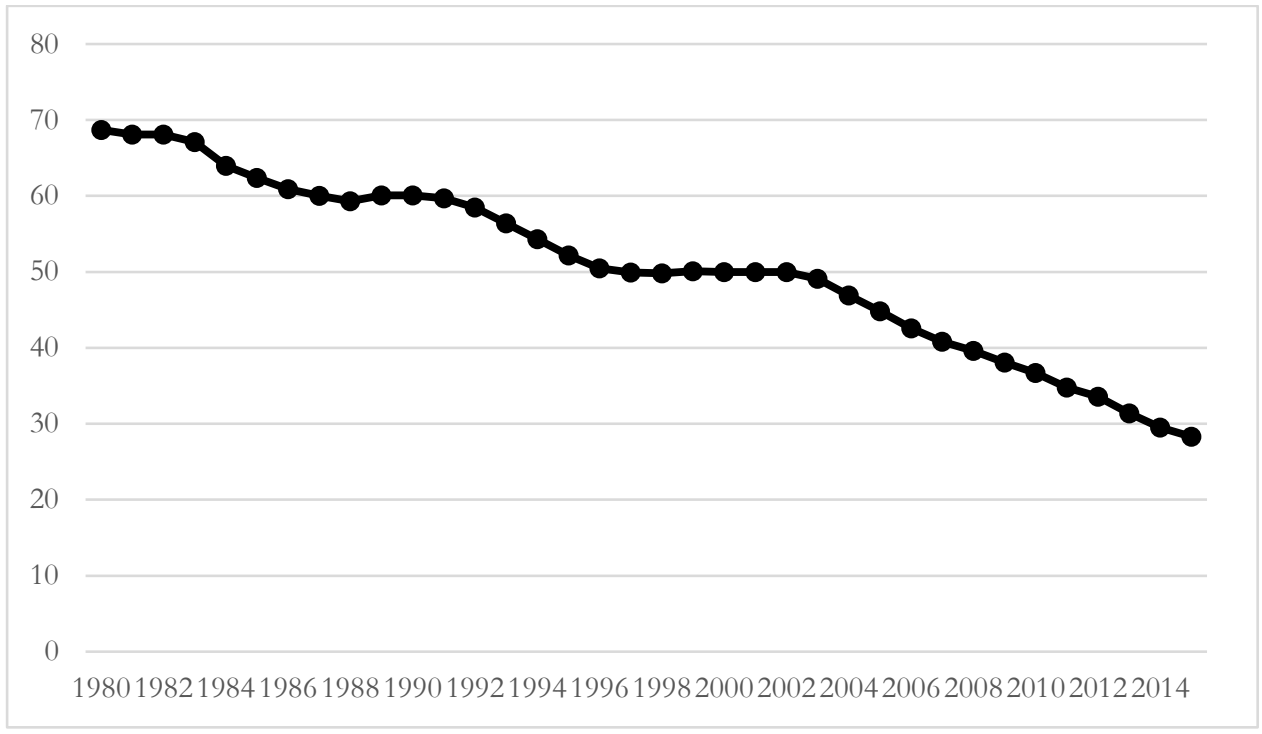

Note: Share of employed persons at year end based on primary sector of employment.

Source: Authors' calculations based on NBS (2016c) data.

This shift out of agriculture and into other sectors is visible in household survey data. Using data from a nationally representative rural household survey, Huang and Rozelle (2012) trace changes over time in the proportion of rural workers engaged in on-farm versus off-farm work. They find that the proportion employed solely in agriculture declined from about 70 per cent in 1995 to 45 per cent in 2007. Conversely, the proportion engaged in off-farm employment rose from 30 per cent in 1995 to 55 per cent in 2007. Roughly one-third of those with off-farm employment, however, also continued to engage in farming.

Changes in incomes and inequality are broadly consistent with the Lewis story. The Lewis story predicts that the structural shift in employment from agriculture to other sectors will not immediately lead to rising wages for urban workers or incomes for the remaining rural population. Such has been the case for China. Hoken and Sato (2017) analyse long-term growth in rural incomes using the CHIP survey data and find that rural income per capita grew slowly from 1988 through 2002. Thereafter, growth in rural income accelerated to about 8 per cent between 2002 and 2007 and to more than 10 per cent between 2007 and 2013. Wages for migrants and for unskilled labour in urban China followed a similar path.

Similar wage patterns have applied to rural-urban migrant workers. As discussed in $\mathrm{Lu}$ (2012), in the late 1990s the wage growth for migrant workers was quite low, but after 2002 began to increase. Figure 5 shows the average annual growth rate of wages of rural-urban migrant workers since the early 2000s, revealing slow wage growth in 2002 followed by wage growth of 6 per cent or faster thereafter. 


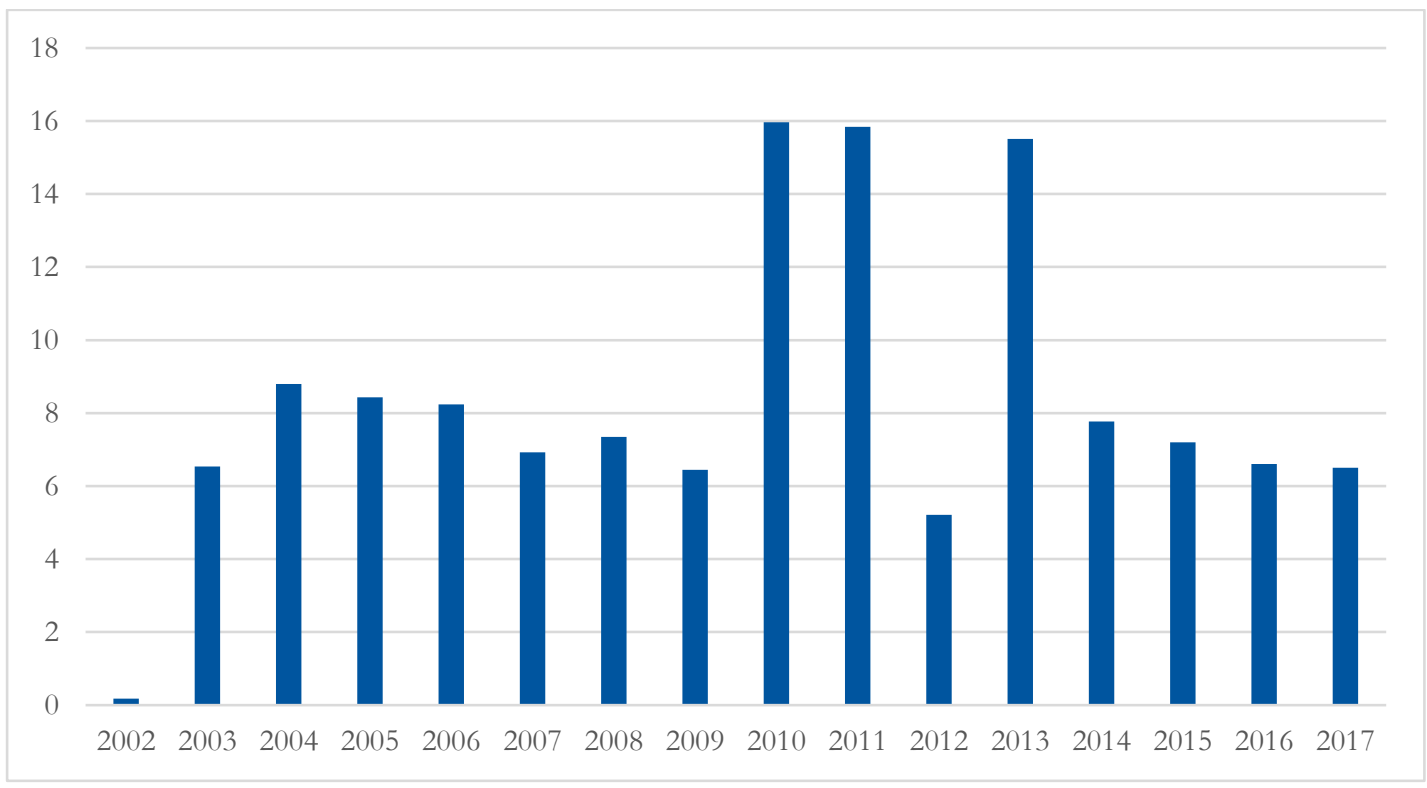

Notes: Wage growth is in real terms (constant prices).

Source: Authors' calculations for 2009-17 are based on the NBS Rural Migrant Workers Survey (NBS 2010, 2012, 2013, 2014, 2015, 2016a, 2017a); for 2002-08 the estimates are based on Lu (2012).

These trends in rural incomes and migrant wages influenced the urban-rural income gap, an important contributor to the rise and recent fall in China's national inequality. Decomposition of national inequality by groups between and within the urban and rural sectors reveals that the urban-rural income gap's contribution to overall inequality rose from roughly 30 per cent in the late 1980 s and mid-1990s to 40 per cent in 2002, and further to 50 per cent in 2007, finally dropping back to 30 per cent in 2013 (Luo et al. 2018).

Although China's path of development is broadly consistent with the Lewis story, several factors modified or distorted its evolution. First, a baby boom in the 1960s caused a demographic bulge that resulted in rapid growth of the working-age population from the 1980s through the early 2000 s, creating downward pressure on wages. Thereafter, the effects of the one-child policy began to kick in, causing a marked slowdown in growth in the labour supply after 2000.

Second, as will be discussed more fully below, incomplete transition has led to ongoing labour market segmentation and hindered labour mobility. Restrictions on migration through the household registration (bukou) system have loosened over time but have not yet been removed. Also, the incomplete reform of farmland property rights has affected the willingness of rural households to leave farming. Knight et al. (2011) argue that ongoing segmentation of the labour market has caused labour scarcity in urban areas and labour surplus in rural areas to coexist. Recent increases in the wages of unskilled workers and migrant workers should be understood in this context.

Aside from structural change and the absorption of surplus labour, economic development can influence income distribution through several other mechanisms. With development comes strengthened fiscal capacity, which allows the public sector to play a larger role in redistribution through taxes and transfers and as a provider of social programmes. China's public sector was large during the Maoist era, but with the implementation of economic reforms fiscal revenues shrank considerably, reaching a low point in the mid-1990s (Lin 2009). Following fiscal reforms in 1994 and with continued economic growth, China's public sector recovered (Lin 2009). With that 
recovery, and especially since 2003 , more resources began to be devoted to building a stronger social welfare system.

Figure 6 shows expenditures on education, social security, and welfare programmes such as dibao (the minimum income guarantee) as a share of total budgetary expenditures, which have grown during this period. ${ }^{1}$ Government spending on social security and employment programmes has remained at around 11 per cent of total budgetary expenditures. The shares of budgetary spending on health and agriculture have increased. The rising share of expenditures on agriculture reflects a series of pro-rural policies starting under the $\mathrm{Hu}$-Wen administration. These pro-rural policies have included grain subsidies and farm supports, in addition to the new rural pension scheme, new rural medical insurance scheme, and new rural poverty-alleviation programmes such as the rural dibao programme. Many poor and low-income rural households have benefited from these policies. The distributional impact of China's expanding social welfare programmes will be discussed more fully in Section 5.

Figure 6: The shares of fiscal spending on education, medical insurance, social security, and agriculture in total budgetary expenditures in China

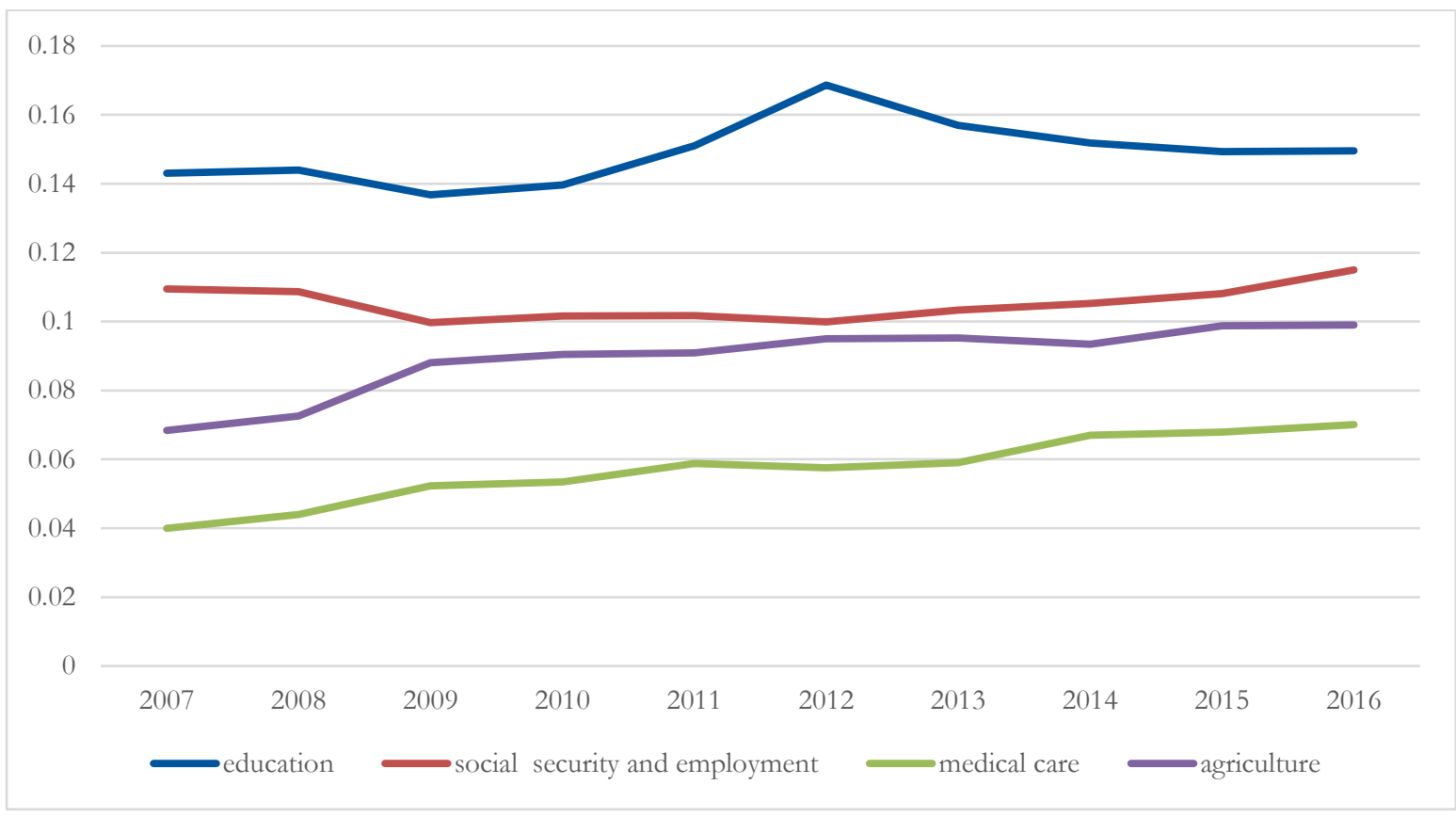

Notes: Calculated using budgetary fiscal revenue and expenditure data published by the National Bureau of Statistics.

Source: Authors' calculations based on NBS (2017b) data.

Development can go hand in hand with increased trade and globalization, with implications for income distribution through its differential impact on regional development as well as on the distribution of wage earnings. China has in fact experienced a marked increase in its levels of trade, especially since its entry into the WTO at the end of 2001 (Figure 7). China's trade expansion did not occur equally among regions and provinces. It started in the eastern coastal region, which is closest to international markets, and gradually spread inland to the central and western regions. Consequently, China's opening to international markets contributed to the widening of regional

\footnotetext{
1 Apart from the budgetary revenue and expenditures, the government also has the extra-budgetary revenue and expenditures which are currently around 10 per cent of the budgetary ones. During 2007-10, the extra-budgetary spending on education accounted for 36-43 per cent of total extra-budgetary expenditures.
} 
income gaps. Furthermore, rapid growth of exports increased the demand for unskilled workers and helped to accelerate the absorption of China's rural surplus labour. The trade story thus helps explain why the wages of unskilled workers and rural migrant workers have increased more rapidly than the wages of other workers in recent years. The role of trade in China's distributional story has received little attention in the literature. Research on this topic would be valuable.

Figure 7: Growth of exports and imports of China

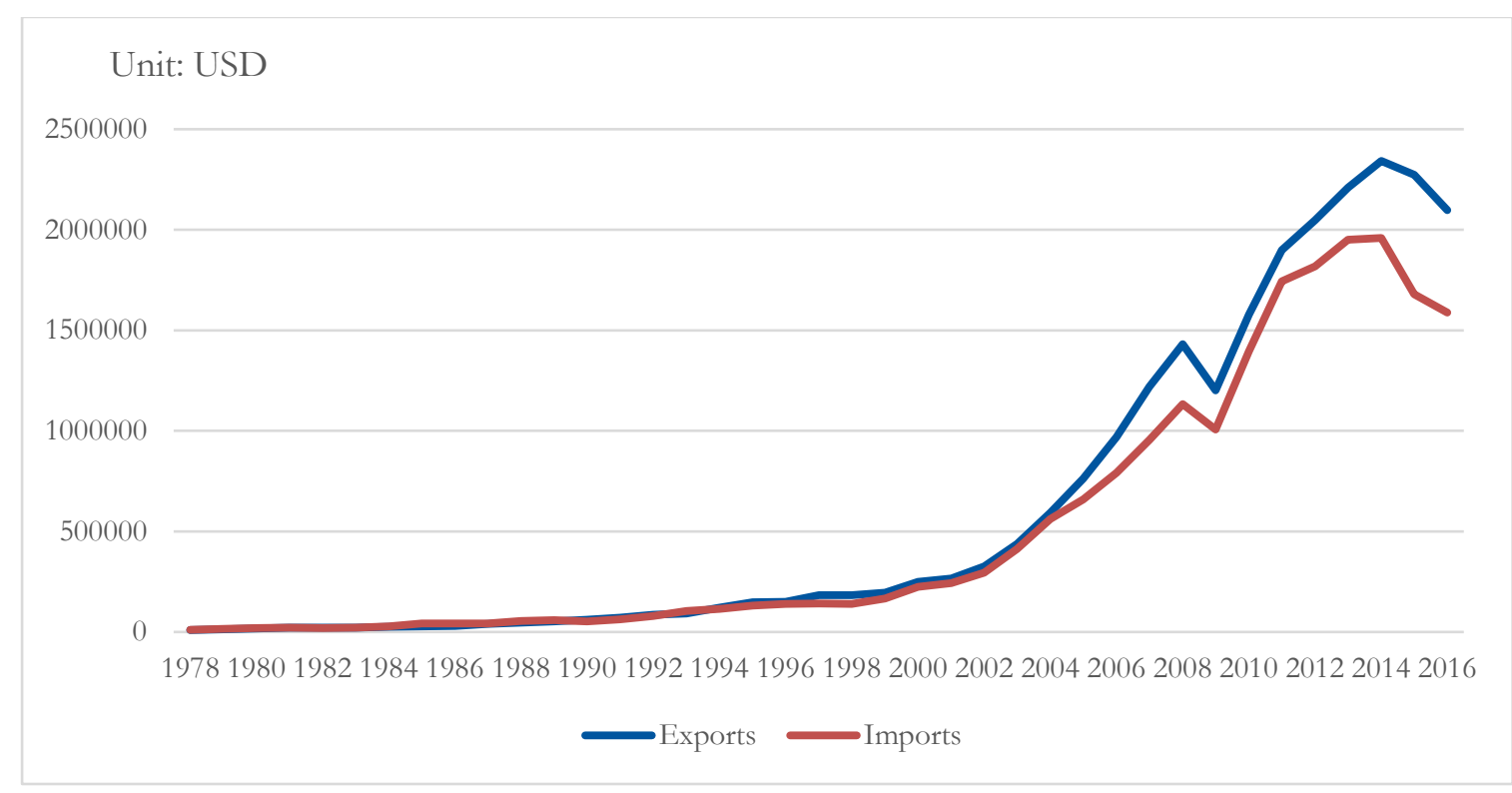

Notes: Calculated using data published by the National Bureau of Statistics.

Source: Source: Authors' calculations based on NBS (2017b) data.

\section{$4 \quad$ Economic transition}

Socialist economies differ from market economies in three major regards. First, the allocation of goods, labour, and capital is done through planning rather than markets. Second, wages are set administratively, and the distribution of income is based on labour or work performed and governed by the principle of egalitarianism. Third, private ownership is minimized; capital and assets are owned by the state and collectives. Private individuals do not receive income from capital.

During much of the Maoist era, these three pillars of socialism characterized China's economy. In rural areas, home to most of the population, production was carried out by collective farms that organized labour and paid workers in an egalitarian fashion based on work points. Urban labour was governed by planned allocation of workers to jobs, typically for lifetime employment in the same work unit, with wage scales fixed by planners. The wage structure minimized wage differentials, which were largely related to seniority. In both rural and urban areas, individuals and households did not own private property, except that rural households were allowed to construct their own housing. This system did not eliminate income gaps-gaps persisted between the urban and rural sectors and in rural areas between richer and poorer localities-but overall income inequality was exceedingly low. Available estimates of the Gini coefficient for the 1970s are generally at or below 0.3 , very low by international standards especially for a large, diverse economy (Xue et al. 2014). 
Economic transition refers to reforms in these three pillars of socialism. Starting in 1978, China embarked on such a transition. The transition in rural areas began in the early 1980s with the replacement of collective farming by household farming under the household responsibility system. Although the household responsibility system did not constitute full privatization-land continued to be collectively owned-some property rights were transferred to households. Households were now given the rights to make production decisions and to keep the earnings from their productive activities. Incomes were now determined by the returns to farming by individual households rather than through egalitarian distribution by collective farms.

Concurrently, the government transformed the system of allocation in rural areas. Step by step it eliminated the planning of farm production, procurement and sales, and prices. By the 1990s agricultural products were largely allocated through markets. The government also lifted restrictions on the expansion of local rural industry. The ensuing rapid development of the socalled township and village industries, which operated outside of the plan, generated employment and income for the rural population, although with variation among regions and localities so that access to such employment and income was uneven.

Not surprisingly, these transition measures led to a marked upswing in rural inequality. Most estimates of the Gini coefficient in rural China for the late 1970s and early 1980s are around 0.2 (Xue et al. 2014). Estimates based on the CHIP data for 1988 (Hoken and Sato 2017) show a substantially higher 0.353, rising further to 0.419 in 1995.

After the mid-1990s, rural inequality declined and then remained fairly stable through 2007 (Hoken and Sato 2017; Luo et al. 2018). The decline and then stabilization of rural inequality suggest that by the mid-1990s the increase in inequality associated with the rural economic transition in ownership, allocation, and income distribution had played out. Meanwhile, the ongoing expansion of off-farm employment, which by the mid-1990s had become pervasive due both to local township and village enterprises and increasingly through migration, also began to moderate inequality.

Transition in the urban sector progressed more slowly. The planned allocation of labour and wages continued through the 1980s; however, firms were encouraged to pursue profits and were given more flexibility to decide on worker pay, e.g. through bonuses tied to performance. Flexibility in terms of labour allocation also increased as new workers were increasingly hired on contracts outside of the plan instead of being allocated to lifetime jobs in work units.

In this initial period of transition, urban workers retained substantial job security, but wage inequality began to increase. Table 2 show an increase in the Gini of urban wage earnings from 0.23 in 1988 to 0.30 in 1995; inequality of urban household income per capita also rose.

Table 2: Gini coefficients of urban wages and income per capita in China, 1988-2013

\begin{tabular}{llllll}
\hline & 1988 & 1995 & 2002 & 2007 & 2013 \\
\hline Wage earnings & 0.230 & 0.301 & 0.345 & 0.379 & 0.384 \\
Household income per capita & 0.231 & 0.332 & 0.311 & 0.335 & 0.352 \\
\hline
\end{tabular}

Notes: Calculated using the CHIP data over urban workers and individuals with urban household registration.

Source: Authors' illustration based on Gustafsson and Ding (2017) and Gustafsson and Wan (2018).

These gradual transition steps continued until the late 1990s, when China undertook a radical restructuring of the urban economy. At this time the government opened the door to the bankruptcy, mergers, and ownership reform of inefficient state-owned enterprises (SOEs) and collective enterprises. Enterprises were now permitted to fire and lay off workers. The result was 
the breaking of the 'iron rice bowl'. Millions of urban workers were laid off or became unemployed, with adverse effects on their incomes. In the short term, urban income inequality rose, primarily due to layoffs and unemployment (Meng 2004). The restructuring, however, was accompanied by the reduction of restrictions on the private sector and reinvigoration of the medium and smallscale enterprises, which were sold off or converted to shareholding. Expansion of these sectors generated jobs. Consequently, by the early 2000s urban employment had largely recovered (Gustafsson and Wan 2018).

A more lasting effect of the urban restructuring was the transformation of the urban wage structure. Seniority-based wage differentials shrank, and wage differentials based on productivity, e.g. as reflected in rapidly increasing returns to education, widened (Deng and Li 2009; Gustafsson and Wan 2018; Zhang et al. 2005). As wages increasingly reflected heterogeneous productive characteristics such as ability and education, the Gini of urban wages rose further to 0.345 in 2002 (Table 2).

Notably, despite rising inequality of wage earnings, during these same few years the inequality of urban household income per capita declined (Table 2). This apparent inconsistency between inequality trends for urban wages and urban household income per capita reflects the growing importance of other sources of urban income, including government social programme transfers.

From the early 2000s on, the government has generally refrained from direct interventions in the labour market, relying on indirect regulatory measures such as the labour contract and minimum wage laws and stimulus spending. Urban wage inequality has continued to rise, with the Gini of urban wage earnings reaching 0.384 in 2013 (Table 2). Unlike in previous decades, however, these recent trends are largely due to shifts in the demand and supply for labour, e.g. resulting from changes in labour demand due to growth, structural change, and technological change, and in labour supply due to the education expansion and demographics. From the early 2000s the inequality of urban income per capita has also increased, with the Gini rising to 0.35 in 2013 (Table 2).

The urban restructuring involved reforms in ownership. For the first time in decades, urban individuals and households became property owners. As noted already, at this time the government officially condoned the development of private ownership of businesses and enterprises, which generated not only employment but also business income and profits for owners and investors. At the same time the government carried out the privatization and marketization of urban housing.

Experiments with urban housing reform had started earlier, but in 1998 the central government adopted the policy nationwide. Within four years (by 2002) 80 per cent of urban public housing had been sold to occupants (Wang 2001; Yang and Chen 2014: chapter 2). The housing reforms meant that although many urban workers lost their jobs, they gained ownership of their housing and at concessionary prices.

The distribution of benefits from the housing reform were not equal, however. Households that happened to be located in work units that had more resources or that were located in more favourable districts or cities, and individuals who had more status, seniority or power within their work units, obtained a larger transfer of housing wealth. Furthermore, the housing reform only benefited workers with formal urban employment, not informal workers or migrant households. In the ensuing years, urban housing prices have appreciated rapidly but unevenly. The consequences for income distribution are evident in the rising share of asset and property income in total income and their growing contribution to income inequality (Figure 3; Luo et al. 2018). 
Transition has affected not only each of the rural and urban sectors, but also the linkages between the two sectors. Under the planned economy, China's household registration (bukou) system highly restricted geographic mobility. Aside from the return of sent-down urban youth to their cities of origin in the early 1980s, mobility continued to be very limited until the mid-1990s when rural workers began to engage in short-term migration. Migration increased over time, and especially from 2000. Since 2000, the pace of urbanization has also accelerated. In the early 1990s more than 80 per cent of China's population was rural and rural-urban migration was minimal; in 2002 the rural population share was 64 per cent and rural-urban migrants accounted for 3 per cent of the population; in 2013 the rural population share had fallen to 46 per cent and the rural-urban migrant share had risen to 13 per cent (Luo et al. 2018).

The resulting massive human relocation from rural to urban China has had implications for inequality. Luo et al. (2018) obtain a rough estimate of the impact of migration on inequality by calculating the Gini coefficient including and excluding rural-urban migrants. For 2013, including migrants reduces the national Gini modestly from 0.4 to 0.43 . This calculation likely understates the impact of migration on inequality because it does not capture the indirect and general equilibrium effects of migration.

Migration and also urbanization have expanded income-earning opportunities for and transformed the composition of income of the rural population. They have affected urban labour markets, greatly expanding the supply of unskilled and low-skilled labour (Gustafsson and Wan 2018). They have influenced trends in the urban-rural income gap, a major contributor to national inequality (Luo et al. 2018).

Since 2000, the composition of household income has also changed due to the growing private sector and self-employment, rising housing prices, the ageing population, and increasing public transfers. At the national level, the share of wage income decreased from 2002 to 2013 by 5.5 per centage points (Figure 3). Moreover, wage income has become more equally distributed among households, as its concentration rate decreased from 0.64 in 2002 to 0.48 in 2013 (Luo et al. 2018). This also has contributed to equalising income inequality.

Nevertheless, trends in wage income have differed between the urban and rural sectors. From 2002 to 2013, urban households experienced a declining share of wage income from 83 per cent to 60 per cent, while for rural households the share of wage income rose from 32 per cent to 34 per cent (calculated from Luo et al. 2018). The declining share of wage income of urban households was accompanied by increasing shares of pension income, which rose from 16 per cent to 19 per cent; family business income, which rose from 3 per cent to more than 6 per cent; and imputed rent on owner-occupied private housing, which rose from 7 per cent to 15 per cent. It is important to realize that although these growing income components have become more equally distributed, their distribution remains relatively unequal. Pension income, for example, is more unequally distributed than wage income (Luo et al. 2018).

\section{$5 \quad$ Incomplete transition}

Although China has made much progress in its economic transition over the past forty years, aspects of the transition remain incomplete. Here we discuss several aspects that have significant consequences for inequality.

Well-functioning markets require strong underpinnings in the form of market regulations, corporate governance, and enforceable legal systems. In China these underpinnings are weak. The 
resulting problems are most visible in asset markets. In both urban and rural areas property rights to land and housing are not enforceable. Local governments can expropriate land and housing from individual households to make way for new development. The affected households are often compensated poorly, while the new development enriches local officials and developers.

Stock markets, established in the 1990s and which have expanded rapidly in the 2000s, remain extremely volatile. Elliott (2015) explains the volatility as arising due to incomplete reforms and ongoing direct government intervention:

Firms are almost totally shielded by government policy from the possibility of a hostile takeover or a forced change of management unless there is a dominant shareholder. Similarly, many company heads can determine dividend levels without great concern over shareholder preferences. Further, corporate governance is weak enough that management is often in a position to divert company assets for their own purposes. Widespread corruption makes this even more of a problem, especially for the many firms where a government entity owns a substantial stake. (Elliott 2015)

Incomplete transition in these areas of property rights contributes to a growing concentration of asset wealth and income. Individuals with existing wealth, connections, or power can take advantage of the incomplete market reforms to enrich themselves. Recent studies on the distribution of wealth in China find that wealth inequality has increased substantially (Knight et al. 2017; Li and Wan 2015. The combination of high income inequality, the rapid rise of housing prices, privatization of SOEs and other assets, and corruption of government officials are contributors to growing wealth inequality.

The unequal distribution of wealth contributes to income inequality. Nearly a quarter of household income growth from 2007 to 2013 was due to increases in income from property, including asset income plus imputed rents on owner-occupied housing (Luo et al. 2018). During this same period the share of income from property increased from less than 10 per cent of household income in 2002 to 17 per cent in 2013 (Figure 3). Because property income is unequally distributed, these trends have had negative implications for income inequality.

Incomplete transition in capital and land property markets has contributed to the emergence of an ultra-rich class and rapid growth of their assets. China's capital market is subject to government intervention and manipulation, enabling those close to government officials to have more opportunities to obtain bank loans and become successful businessmen. Li et al.'s (2018) topincome dataset reveals the importance of land and real estate markets. Most of the super-rich in this dataset come from the real estate and IT industries. The Forbes Rich List in recent years also shows growth in the number of billionaires from these two sectors.

Incomplete reform of the state enterprise sector has contributed to weak corporate governance. State ownership in China has declined substantially but continues to dominate key sectors and firms. SOEs have been transformed into shareholding corporations in which the state owns the majority of or controlling shares. Despite these reforms, SOEs continue to have privileged status and receive special treatment in terms of industrial policies and access to loans and finance. Their relationship with the state and Communist Party remains murky, such that corporate governance is compromised. With respect to income distribution, these characteristics of SOEs create opportunities for corruption and unequal wealth accumulation.

In addition, the insulation of SOE employment and compensation from labour market forces contributes to inequality in wage earnings and benefits. Gustafsson and Wan's (2018) estimates of Mincer urban wage equations for each year of the CHIP survey reveal that after controlling for 
individual characteristics such as education and experience, SOE wages remain higher than those in all other ownership sectors except the foreign-owned enterprise sector; moreover, since 1995 the magnitude of the SOE wage premium has increased.

The bukou system is another area of incomplete transition. Despite substantial loosening of restrictions on migration, a variety of policies and related factors continue to impede labour mobility. The result is ongoing segmentation of the labour market, which tends to elevate wage differentials among regions and between urban and rural workers. Rural migrant workers with rural bukou are discriminated against in terms of employment opportunities, compensation, and access to public services in urban areas. They are referred to as 'second class' (Démurger et al. 2009).

Another important area of incomplete transition is rural land ownership. Rural households have only partial property rights to their farmland. They have the right to cultivate and earn income from their land, and increasingly they have the right to transfer land through rental markets, but they do not have the right to sell their land or use it as collateral. Moreover, they are not protected against confiscation of their land by local governments. The incomplete reform of rural land property rights distorts the distribution of income in ways that increase inequality. It creates an imbalance between poorer rural and richer urban households in terms of their ability to benefit from their real property. It reduces farm productivity and thus depresses income from agriculture, which is the most equalizing component of income. The depressed income from agriculture creates heightened incentives to seek off-farm work. Yet, the fact that rights to the land can be lost if it is not cultivated hinders mobility. These factors distort patterns of income and inequality.

\section{Distributional policies}

In the first decades of the economic reform, China followed a development strategy that emphasized growth of the 'productive forces', that is, a strategy that placed priority on growth of GDP, development of the underlying factors of production, and improved productivity. In reaction to the overly egalitarian policies of the Cultural Revolution, distributional concerns were placed on the back burner, especially after Deng Xiaoping's southern tour in 1992 when he proclaimed that China should 'let some people get rich first'. At that time China did not totally ignore distributional issues, e.g. it invested in a major programme of rural poverty alleviation. Little attention, however, was paid to distributional trends elsewhere. Through the 1980s and 1990s, China's rapid GDP growth was accompanied by unprecedented increases in income inequality. By the late 1990s, income inequality in China was approaching levels found in countries considered to be relatively unequal by international standards.

Concerns about rising inequality led to a shift in development strategy in the early 2000s, when China launched the 'Hu-Wen New Policies' (Hu-Wen xinzheng), including the 'Scientific Outlook on Development' (kexue farhan guan) and 'harmonious society' (hexie shehui) programmes, which emphasized sustainable and equitable growth. Over the following decade, China embarked on an ambitious programme to improve its social welfare system with the aim of achieving universal coverage of social security and social insurance programmes. As of 2013, the main components of these programmes were largely in place, and improvements have continued since.

The major components of China's social welfare system are pensions, health insurance, and cash transfers to the poor. Pensions had previously only existed for urban workers with formal employment. In 2009, the government extended pensions to rural China with the launch of the New Rural Pension Scheme. By 2012, this new programme reportedly covered 100 per cent of 
China's rural counties (Wang 2014). Although the amount of pension payments has remained low, they have increased over time. Still, rural pension benefit levels differ among provinces and counties, with higher payments in the more developed regions. In 2015, for example, rural pension income was 470 yuan per person per month for rural residents of Beijing as compared to 85 yuan in the western province of Gansu.

In 2011, China extended pension benefits in urban areas with the introduction of the new basic urban pension scheme, which was aimed at urban residents without formal employment and those who were ineligible for the pre-existing urban employee pension programmes. In 2014, the new rural and urban basic pension schemes were merged. According to official NBS statistics, enrolment in the combined rural and urban basic pension programmes grew rapidly from essentially zero in 2007 to 497.5 million in 2013. As of 2015, enrolment exceeded 500 million, and pension recipients numbered 148 million.

Like pensions, health insurance had previously been limited to formal sector urban employees. In 2009, health insurance was extended to rural areas nationwide with the adoption of the New Rural Cooperative Medical Scheme. According to official statistics, the programme's coverage increased from 252 million people in 2007 to 487 million people in 2013, with a coverage rate exceeding 95 per cent; during the same period, contributions from individuals and governments rose from about 50 yuan per person to over 300 yuan per person (Meng and Xu 2014). In 2007, the government took a further step and initiated Urban Resident Basic Medical Insurance, a voluntary programme providing health insurance to urban residents who do not have formal employment. By 2009, this programme was offered in almost all of China's cities (Liu and Zhao 2014). Enrolment in the programme rose from 43 million people in 2007, its first year, to 296 million people in 2013, and further to 377 million people in 2015.

By increasing the affordability of medical care, these health insurance programmes have the potential to improve health outcomes and labour productivity, and thus reduce the use of household savings for self-insurance. In these ways China's health insurance programmes can have an indirect but positive impact on household income. Nevertheless, participant contributions and levels of reimbursement vary regionally, and levels of reimbursement remain low.

Since the 1980s, China has pursued an active poverty reduction agenda in rural areas. In the early years, China's rural poverty programmes were designed to reduce poverty by developing the local economy. They funded economic development in designated poor rural regions and counties, with the idea that low economic development in the poor localities was the main cause of poverty. This strategy, together with macroeconomic growth more broadly, contributed to a marked reduction in poverty.

By the 2000s, the pattern of poverty in China had become more dispersed and required a different approach. In response, China adapted its policy alleviation strategy and began targeting smaller areas (e.g. villages instead of counties) and households. The Minimum Livelihood Guarantee or dibao programme, a means-tested cash transfer programme targeted at households, was first established in cities in 1999 and was expanded significantly in urban areas in the early 2000s. Official statistics indicate that by 2007 the number of recipients in the urban dibao programme was 23 million, since which time the numbers have remained at about 20 million.

A similar, rural dibao programme was initiated on a pilot basis in 2004 and adopted in rural areas nationwide in 2007. The rural dibao programme grew rapidly to 54 million recipients in 2013. Concurrently, the generosity of the rural programme rose, with rural dibao expenditures per recipient increasing from 446 yuan per person per year in 2007 to 1,609 yuan per person per year 
in 2016 (Golan et al. 2017). The expansion of the urban and rural dibao programmes has had both direct and indirect impacts on measured income levels and inequality.

Cai and Yue (2018) evaluate the distributional impact of China's expanding social welfare programmes, specifically the impact of China's pension programmes (formal sector, urban resident, and rural resident pension programmes), the minimum guaranteed income or dibao programme, medical insurance reimbursements, farmer subsidies, and some other smaller programmes. The study compares the impact of these social security programme transfers in 2002, at the start of the new efforts to build a comprehensive social welfare system, to that in 2013, when much of that system was in place.

The study finds that the amount of social security transfers increased markedly between 2002 and 2013, rising from 9 per cent to 14 per cent of household income before taxes and transfers. The effects of the programmes on income inequality, however, were mixed. On the positive side, the transfers reduced inequality in the sense that measured inequality including the transfers is lower than that excluding the transfers. Moreover, the transfers became more equalizing over time, a reflection of the introduction and expansion of programmes to previously uncovered rural and informal urban residents.

On the negative side, the extent to which China's social welfare programmes served as a mechanism for redistribution was compromised by the fact that their benefits went disproportionately to the wealthier, urban population. This imbalance is largely due to the formal sector pension programme, which accounted for more than 80 per cent of total social welfare transfers in both 2002 and 2013. Importantly, formal sector pensions went almost entirely to the relatively well-off formal urban population (Cai and Yue 2018).

Aside from China's pension, dibao, health, and other social welfare programmes, a few other government programmes with distributional objectives deserve mention. First, since the late 1990s the Chinese government has adopted major initiatives to expand rural secondary education and to increase university enrolments. Official statistics indicate that the progression rate from junior to senior secondary school rose from 50 per cent in 2000 to 81 per cent in 2007, and further to 91 per cent in 2013. According to UNESCO data, gross enrolment rates in secondary education rose from 61 per cent in 2000 to 73 per cent in 2007, and further to 96 per cent in 2013; tertiary enrolment rates rose from 8 per cent in 2000 to 21 per cent in 2007 and 30 per cent in 2013.

The expansion of secondary and tertiary education has helped narrow gaps in education levels (e.g. between women and men). These changes in educational attainment have implications for recent trends in income and inequality. For example, Gustafsson and Wan (2018) reports that the returns to education rose from 1988 to 2007 but declined thereafter. Gustafsson and Wan (2018) attributes the decline in the returns to education in part to the increased supply of workers with university education.

Second, minimum wage policies, initially adopted in the 1990s, have targeted the low-wage segment of China's urban labour market. In the early years of these programmes, minimum wage levels were low and not strictly enforced. After implementation of the New Labour Contract Law in 2008, minimum wage levels and their enforcement have increased. To some extent these efforts are the result of political competition by local governments responding to the central government's call for a higher wage share in national income. For instance, in July 2010 Hainan province and Henan province increased their provincial minimum wages by 30 per cent and 33 per cent, respectively. In 2011, at least five provinces raised their minimum wages by more than 20 per cent, and in 2012-13 twenty-seven provinces increased their minimum wages (Li et al. 2014). Several 
studies have investigated the consequences of these minimum wage policies on the urban wage distribution (Li and Ma 2015; Lin and Yun 2016; Ma and Li 2017).

\section{$7 \quad$ Conclusions}

From the late 1970s through the early 2000s, income inequality in China rose from a low level to one that is relatively high by international standards. Standard estimates indicate that the level of inequality has plateaued and declined modestly since 2007, suggesting that China may have turned the corner in the Kuznets inverted U. Potential bias in recent estimates of China's inequality due to the increased difficulty of capturing China's emerging ultra-rich class, however, raises questions about the path of China's inequality in the past decade.

China is both a developing economy and an economy in transition. Consequently, conventional development theories only go part way to explaining China's story of inequality. The special dynamics of income inequality in China during the past forty years need explanations that reflect China's unique development path, completed aspects of its economic transition, and still incomplete facets of its economic transition.

China's economic transition has been successful in many regards, but some facets of the transition remain incomplete. The transition aspect of China's economy may have elongated the rise of income inequality beyond what one would expect based on Lewis's two-sector model, and China's incomplete transition has likely dampened the mechanisms that normally bring about the downturn in Kuznets' inverted U.

Delayed reforms in the bukou system have led a persistent, widening income gap between urban and rural households, even with a large population of rural migrants moving into cities. Unchanged political reform associated with excessive government invention into economic activities have resulted in corruption and rent-seeking and have generated an excessive number of super-rich businessmen and disguised rich officials. Incomplete reform of the state-owned enterprise sector has preserved their monopolistic position in some sectors and has contributed to ongoing widening wage differentials among sectors.

How does China's experience in dealing with rising income inequality compare to that in other developing countries? First, China's experience highlights the importance of income growth for poor and low-income households. Despite the increase in income inequality, China has not yet experienced severe social instability. This is likely due in part to the fact that, unlike some other developing countries, poor and lower-income households have enjoyed substantial income growth. Thus, even though income inequality has risen to a relatively high level, the poor as well as the rich enjoyed the benefits from China's rapid economic growth. By some definitions, then, Chinese economic growth has been inclusive.

Second, China's experience highlights the importance of redistributive government policies and programmes. Evidence suggests that in recent years the expansion of redistributive policies has begun to play a role in moderating income inequality. Such policies are important not only for their actual impact on income distribution, but also for their symbolic function. They signal the regime's commitment to a certain vision of social welfare.

What will be the direction of China's income inequality in the future? China's past experience suggests that future trends will depend on whether China is able to address several challenges. First, the contribution of segmentation of labour markets and incomplete and distorted capital 
markets to widening income inequality highlights the need to pursue measures that promote wellfunctioning, equitable market mechanisms. Second, direct redistributive policies must be accompanied by steps to fight corruption and rent-seeking that result from government interventions and the political system.

Third, signs of encouraging trends in income inequality may not be sustainable if wealth inequality continues to rise. Steps are needed to address the widening inequality of wealth and broaden opportunities for wealth accumulation by lower-income groups. Our findings thus suggest that in the future China's ability to transition from a high-inequality to a low-inequality economy is not guaranteed. It will require ongoing vigilance, further economic and political reforms, and the strengthening and expansion of redistributive policies.

\section{References}

Cai, M., and X. Yue (2018). 'The Redistributive Role of Government Social Security Transfers on Inequality in China'. Unpublished Manuscript.

China Institute for Income Distribution (n.d.). 'CHIP Dataset Homepage'. [Online]. Available at: http://ciid.bnu.edu.cn/chip/index.asp (accessed August 2018).

China Net (2017). 'Ning Jiwei: China's Gini coefficient is generally declining, and the urban-rural income gap is narrowing'. [Online]. Available at: http://finance.china.com.cn/ news/gnjj/20170120/4077373.shtml (accessed August 2018).

Démurger, S., M. Gurgand, S. Li, and X. Yue (2009). 'Migrants as Second-class Workers in Urban China? A Decomposition Analysis'. Journal of Comparative Economics, 37(4): 610-28.

Deng, Q., and S. Li (2009). 'What Lies Behind Rising Earnings Inequality in Urban China? Regression-based Decompositions’. CESifo Economic Studies, 55(3-4): 598-623.

Elliott, D.J. (2015). 'Op-ed: China Will Struggle with Its Stock Markets Until It Completes Reforms', The Brookings Institution. Available at: https://www.brookings.edu/opinions/ china-will-struggle-with-its-stock-markets-until-it-completes-reforms/ (accessed August 2018).

Golan, J., T. Sicular, and N. Umapathi (2017). 'Unconditional Cash Transfers in China: Who Benefits from the Rural Minimum Living Standard Guarantee (Dibao) Program?'. World Development, 93(5): 316-36.

Gustafsson, B., and S. Ding (2017). 'Unequal Growth: How Household Incomes and Poverty in Urban China Have Developed Since 1988, With an Emphasis on the Period from 2007 to 2013'. University of Western Ontario Centre for Human Capital and Productivity Working Paper 2017-18. Available at:

https://ir.lib.uwo.ca/cgi/viewcontent.cgi?article=1130\&context=economicscibc (accessed August 2018).

Gustafsson, B., and H. Wan (2018). 'Wage Growth and Wage Inequality in Urban China: 19882013'. WIDER working paper 2018/163. Helsinki: UNU-WIDER.

Hoken, H., and H. Sato (2017). 'Public Policy and Long-Term Trends in Inequality in Rural China 1988-2013'. Western University Centre for Human Capital Productivity Working Paper No. 2017-16. Available at: https://ir.lib.uwo.ca/economicscibc/125/ (August 2018).

Huang, J., and S. Rozelle (2012). 'China's Labor Transition and the Future of China's Rural Wages and Employment'. Background Paper for World Development Report 2013. Available at: 
http:/ / siteresources.worldbank.org/EXTNWDR2013/Resources/8258024-

1320950747192/8260293-1320956712276/8261091-

1348683883703/WDR2013_bp_China_Labor_Transition.pdf (accessed August 2018).

Knight, J., Q. Deng, and S. Li (2011). 'The Puzzle of Migrant Labor Shortage and Rural Labor Surplus in China'. China Economic Review, 22(4): 585-600.

Knight, J., S. Li, and H. Wan (2017). 'The Increasing Inequality of Wealth in China, 2002-2013'. University of Western Ontario Centre for Human Capital and Productivity Working Paper 2017-15. Available at:

https://ir.lib.uwo.ca/cgi/viewcontent.cgi?article=1127\&context=economicscibc (accessed August 2018).

Li, Q., S. Li, and H. Wan (2018 forthcoming). 'Top Incomes in China: Data Collection and the Impact on Income Inequality'. WIDER working paper 2018, forthcoming. Helsinki: UNUWIDER.

Li, S., and X. Ma (2015). 'Impact of Minimum Wage on Gender Wage Gaps in Urban China'. IZA Journal of Labor and Development, 4(1): 1-22.

Li, S., H. Sato, T, Sicular, and X. Yue (eds) (forthcoming). Changing Trends in China's Inequality: Evidence, Analysis and Prospects. New York, NY: Oxford University Press.

Li, S., and H. Wan (2015). 'Evolution of Wealth Inequality in China'. China Economic Journal, 8(3): 264-87.

Li, S., L. Ye, and L. Xiong (2014). 'Understanding Impacts of Minimum Wage Policy on Labor Market in China'. Presentation at the International Conference on Minimum Wage Policy, Hong Kong University of Science and Technology, September.

Lin, C., and M.-S. Yun (2016). 'The Effects of the Minimum Wage on Earnings Inequality: Evidence from China'. In L. Cappellari, S.W. Polachek, and K. Tatsiramos (eds), Income Inequality Around the World (Research in Labor Economics, Volume 44). Bingley, UK: Emerald Group Publishing Limited.

Lin, S. (2009). 'The Rise and Fall of Chinese Government Revenue'. EAI Working Paper 150. Singapore: National University of Singapore East Asian Institute. Available at: http://www.eai.nus.edu.sg/publications/files/EWP150.pdf (accessed August 2018).

Liu, H., and Z. Zhao (2014). 'Does Health Insurance Matter? Evidence from China's Urban Resident Basic Medical Insurance'. Journal of Comparative Economics, 42(4): 1007-20.

Lu, F. (2012). 'Wage Trend of Rural Migrant Workers: 1979-2010'. China Social Sciences (in Chinese), 7: 47-67.

Luo, C., S. Li, and T. Sicular (2018). 'The Long-Term Evolution of Income Inequality and Poverty'. WIDER Working Paper, forthcoming.

Ma, X., and S. Li (2017). 'The Effects of Minimum Wage on Wage Distribution in Urban China: Evidence from the CHIP Data'. Western University Centre for Human Capital and Productivity Working Paper 2017-24. Available at: https://ir.lib.uwo.ca/economicscibc/136/ (accessed August 2018).

Meng, Q., and K. Xu (2014). 'Progress and Challenges of the Rural Cooperative Medical Scheme in China'. Bulletin of the World Health Organization, 92(6): 447-51.

Meng, X. (2004). 'Economic Restructuring and Income Inequality in Urban China'. Review of Income and Wealth, 50(3): 357-79. 
NBS (2010). '2009 Migrant Workers Monitoring Survey Report'. [Online]. Available at: http://www.stats.gov.cn/ztjc/ztfx/fxbg/201003/t20100319_16135.html http://www.stats.gov.cn/ztjc/ztfx/fxbg/201003/t20100319_16135.html (accessed 18 December 2018).

NBS (2012). '2011 China Migrant Workers Survey and Monitoring Report'. [Online]. Available at: http://www.stats.gov.cn/ztjc/ztfx/fxbg/201204/t20120427_16154.html (accessed 18 December 2018).

NBS (2013). '2012 National Migrant Workers Monitoring Survey Report'. [Online]. Available at: http://www.stats.gov.cn/tjsj/zxfb/201305/t20130527_12978.html (accessed 18 December 2018).

NBS (2014). '2013 National Migrant Workers Monitoring Survey Report'. [Online]. Available at: http://www.stats.gov.cn/tjsj/zxfb/201405/t20140512_551585.html_ (accessed 18 December 2018).

NBS (2015). '2014 National Migrant Workers Monitoring Survey Report'. [Online]. Available at: http://www.stats.gov.cn/tjsj/zxfb/201504/t20150429_797821.html (accessed 18 December 2018).

NBS (2016a). '2015 Migrant Workers Monitoring Survey Report'. [Online]. Available at: http://www.stats.gov.cn/tjsj/zxfb/201604/t20160428_1349713.html（accessed 18 December 2018).

NBS (2017a). '2016 Migrant Workers Monitoring Survey Report'. [Online]. Available at: http://www.stats.gov.cn/tjsj/zxfb/201704/t20170428_1489334.html_(accessed 18 December 2018).

NBS (2016b). China Yearbook of Household Survey 2016. Beijing: China Statistics Press.

NBS (2016c). China Statistical Yearbook 2016. Beijing: China Statistics Press.

NBS (2017b). China Statistical Yearbook 2017. Beijing: China Statistics Press.

Wang, D. (2014). 'China’s Pension System Reform'. Presentation at the Regional Consultation on Strengthening Income Support for Vulnerable Groups in Asia and the Pacific, UNESCAP Subregional Office for East and North-East Asia, Incheon, Republic of Korea, March 2627. Available at: http://www.unescap.org/sites/default/files/ISS-Meeting_item3-dewenwang.pdf (accessed June 2017).

Wang, Y. (2001). 'Urban Housing Reform and Finance in China: A Case Study of Beijing'. Urban Affairs Review, 36(5): 620-45.

Xue, J., C. Luo, and S. Li (2014). 'Globalization, Liberalization and Income Inequality: The Case of China'. Singapore Economic Review, 59(1): 1450002 (21 pages).

Yang, Z., and J. Chen (2014). Housing Affordability and Housing Policy in Urban China. New York, NY: Springer.

Zhang, J., Y. Zhao, A. Park, and X. Song (2005). 'Economic Returns to Schooling in Urban China 1988-2001'. Journal of Comparative Economics, 33(4): 730-52. 